\title{
Quality control ranges for testing broth microdilution susceptibility of Flavobacterium columnare and F. psychrophilum to nine antimicrobials
}

\author{
Charles M. Gieseker ${ }^{1, *}$, Tamara D. Mayer ${ }^{1}$, Tina C. Crosby ${ }^{1}$, Jeremy Carson ${ }^{2}$, \\ Inger Dalsgaard ${ }^{3}$, Ahmed M. Darwish ${ }^{4}$, Patricia S. Gaunt ${ }^{5}$, Dana X. Gao ${ }^{5}$, \\ Hui-Min Hsu ${ }^{6}$, Tsang L. Lin ${ }^{9}$, J. Lindsay Oaks ${ }^{7}$, Melissa Pyecroft ${ }^{2}$, Charlene Teitzel ${ }^{7}$, \\ Temdoung Somsiri ${ }^{8}$, Ching C. $\mathrm{Wu}^{9}$ \\ ${ }^{1}$ Food and Drug Administration, Center for Veterinary Medicine, Office of Research, Laurel, Maryland 20708, USA \\ ${ }^{2}$ Fish Health Unit, Department of Primary Industries, Parks, Water \& Environment, Launceston, Tasmania 7249, Australia \\ ${ }^{3}$ National Veterinary Institute, Technical University of Denmark, 1870 Frederiksberg C, Denmark \\ ${ }^{4}$ United States Department of Agriculture, Agriculture Research Service, Harry K. Dupree Stuttgart National Aquaculture \\ Research Center, Stuttgart, Arkansas 72160, USA \\ ${ }^{5}$ Thad Cochran National Warmwater Aquaculture Center, College of Veterinary Medicine, Mississippi State University, \\ Stoneville, Mississippi 38766, USA \\ ${ }^{6}$ Wisconsin Veterinary Diagnostic Laboratory, University of Wisconsin, Madison, Wisconsin 53706, USA \\ ${ }^{7}$ Washington Animal Disease Diagnostic Laboratory, University of Washington, Pullman, Washington 99164, USA \\ ${ }^{8}$ Inland Aquatic Animal Health Research Institute, Kasetsart University, Jatuchak, Bangkok 10900, Thailand \\ ${ }^{9}$ Animal Disease Diagnostic Laboratory, Purdue University, West Lafayette, Indiana 47907, USA
}

\begin{abstract}
A multi-laboratory broth microdilution method trial was performed to standardize the specialized test conditions required for the fish pathogens Flavobacterium columnare and $F$. psychrophilum. Nine laboratories tested the quality control (QC) strains Escherichia coli ATCC 25922 and Aeromonas salmonicida subsp. salmonicida ATCC 33658 against 10 antimicrobials (ampicillin, enrofloxacin, erythromycin, florfenicol, flumequine, gentamicin, ormetoprim/sulfadimethoxine, oxolinic acid, oxytetracycline, and trimethoprim/sulfamethoxazole) in diluted (4 $\left.\mathrm{g} \mathrm{l}^{-1}\right)$ cationadjusted Mueller-Hinton broth incubated at 28 and $18^{\circ} \mathrm{C}$ for $44-48$ and $92-96 \mathrm{~h}$, respectively. QC ranges were set for 9 of the 10 antimicrobials. Most of the minimal inhibitory concentration (MIC) distributions (16 of 18, 9 drugs at both temperatures) for A. salmonicida ATCC 33658 were centered on a single median $\mathrm{MIC} \pm 1$ two-fold drug dilution resulting in a $\mathrm{QC}$ range that spanned 3 dilutions. More of the E. coli ATCC 25922 MIC distributions (7 of 16) were centered between 2 MIC dilutions requiring a QC range that spanned 4 dilutions. A QC range could not be determined for E. coli ATCC 25922 against 2 antimicrobials at the low temperature. These data and their associated QC ranges have been approved by the Clinical and Laboratory Standards Institute (CLSI), and will be included in the next edition of the CLSI M49-A Guideline. This method represents the first standardized reference method for testing fish pathogenic Flavobacterium spp.
\end{abstract}

KEY WORDS: Standard methods $\cdot$ Antimicrobial susceptibility testing $\cdot$ Fish $\cdot$ Flavobacteria

\section{INTRODUCTION}

The nutritionally fastidious aquatic gliding bacteria Flavobacterium columnare and F. psychrophilum are major fish pathogens that cause significant disease losses in freshwater aquaculture worldwide (Waka- bayashi \& Egusa 1966, Bernardet 1989, Holt et al. 1993, Wagner et al. 2002, Nematollahi et al. 2003, Pulkkinen et al. 2010). They represent an important group that need standard antimicrobial susceptibility testing (AST) methods. The Clinical and Laboratory Standards Institute (CLSI) provides 2 consensus- 
approved guidelines with reference methods and quality control $(\mathrm{QC})$ criteria for disk diffusion and broth dilution susceptibility testing of non-fastidious aquatic bacteria (CLSI $2006 \mathrm{a}$, b) based on the work of Miller et al. $(2003,2005)$. CLSI groups fastidious aquatic bacterial pathogens that have similar growth condition requirements, and offers potential media and incubation modifications; however, no standard reference methods or QC criteria have been developed to date.

In general, 3 AST methods can be developed as standard CLSI reference methods: disk diffusion, broth dilution, and agar dilution. Dilution techniques (agar and broth) are preferable to disk diffusion since these tests yield a minimal inhibitory concentration (MIC) that can be directly compared to the pharmacokinetics of the drug in the animal. However, disk diffusion is popular among fish disease diagnosticians because the method is inexpensive, easy to perform, and better suits laboratories that test only a small number of isolates infrequently. Disk diffusion is not as practical for testing the fish-pathogenic Flavobacteria, in particular Flavobacterium columnare, since the gliding motility of the bacterium distorts the margin of the inhibitory zone (Farmer 2004). Alternatively, agar dilution, the 'gold standard' method, has been used to test F. psychrophilum (Bruun et al. 2000, Schmidt et al. 2000, Michel et al. 2003), but the method is fairly labor intensive and does not lend itself well to ad hoc testing. Therefore, we determined that broth dilution, specifically broth microdilution, was the best option to develop as a standard reference AST method.

The CLSI broth dilution testing guideline for aquatic bacteria (M49-A) suggests using diluted Mueller-Hinton broth $\left(\mathrm{MHB}_{;} 3 \mathrm{~g} \mathrm{l}^{-1}\right.$ ) for testing Flavobacterium columnare, F. psychrophilum, and $F$. branchiophilum. The guide also suggests that F. psychrophilum and F. branchiophilum may need additional supplements of $5 \%$ horse or fetal calf serum and/or $\mathrm{NaCl}$ (CLSI 2006b). These recommendations were partly based on the disk diffusion methods developed by Hawke \& Thune (1992) for testing $F$. columnare. However, more recent research has determined that only diluted MHB $\left(4 \mathrm{~g} \mathrm{l}^{-1}\right)$ is needed for broth microdilution testing of F. columnare, and that $\mathrm{Ca}^{++}$and $\mathrm{Mg}^{++}$, typically added to MHB for broth dilution susceptibility testing, may not be needed (Farmer 2004, Darwish et al. 2008). Preliminary work at the Food and Drug Administration, Center for Veterinary Medicine, Office of Research (Laurel, MD, USA) found diluted MHB (4 $\mathrm{g} \mathrm{l}^{-1}$ ) yielded consistent MICs for $F$. columnare and F. psychrophilum isolates, as well as for both QC strains referenced in CLSI M42-A and M49-A guidelines. We had too few isolates to test $F$. branchiophilum adequately. We also found that $\mathrm{Ca}^{++}\left(4 \mathrm{mg} \mathrm{l}^{-1}\right)$ and $\mathrm{Mg}^{++}\left(2 \mathrm{mg} \mathrm{l}^{-1}\right)$ were needed for testing F. psychrophilum, and serum supplementation was not necessary for testing of $F$. columnare or $F$. psychrophilum. $\mathrm{NaCl}$ supplementation was not considered, since $F$. columnare and F. psychrophilum generally do not grow in media containing more than $0.5 \% \mathrm{NaCl}$ (Bernardet \& Grimont 1989). Ultimately, we found diluted MHB $\left(4 \mathrm{~g} \mathrm{l}^{-1}\right)$ with $\mathrm{Ca}^{++}\left(4 \mathrm{mg} \mathrm{l}^{-1}\right)$ and $\mathrm{Mg}^{++}\left(2 \mathrm{mg} \mathrm{l}^{-1}\right)$ was a good medium for broth dilution testing of both F. columnare and F. psychrophilum isolates.

Optimal incubation conditions for Flavobacterium columnare and $F$. psychrophilum also needed to be established. We found that incubating $F$. columnare at $28^{\circ} \mathrm{C}$ for 44 to $48 \mathrm{~h}$ as recommended by the CLSI (2006b) and Darwish et al. (2008) worked well. In contrast, a slightly higher incubation temperature $\left(18^{\circ} \mathrm{C}\right)$ and longer incubation time $(96 \mathrm{~h})$ than recommended by the CLSI was needed for F. psychrophilum (C. M. Gieseker et al. unpubl.). Although $18^{\circ} \mathrm{C}$ is just above the recommended growth temperature of $15^{\circ} \mathrm{C}$ for $F$. psychrophilum (CLSI 2006b), the bacterium grows similarly at both temperatures (Holt et al. 1989). A longer incubation time is needed as the shorter incubation times of 44 to $72 \mathrm{~h}$, as recommended by the CLSI, yielded misleadingly low MICs in preliminary testing (C. M. Gieseker et al. unpubl.).

To establish a standard AST method for fishpathogenic Flavobacteria, drug susceptibility testing ranges were needed for the QC strains under the altered test conditions optimized for these bacteria. Herein, we report the results of a multi-laboratory standardization trial that established MIC QC ranges of 9 antimicrobials for the QC strains Escherichia coli ATCC 25922, NCIMB 12210 and Aeromonas salmonicida subsp. salmonicida ATCC 33658, NCIMB 1102. The CLSI Subcommittee on Veterinary Antimicrobial Susceptibility Testing (VAST) - Aquaculture Working Group analyzed the data and proposed QC ranges to the VAST Subcommittee. The ranges presented here were unanimously accepted for inclusion in the next edition of the CLSI M49-A Guideline. These QC ranges and testing methods provide the first standard AST reference methods for the important fish pathogens Flavobacterium columnare and F. psychrophilum. 


\section{MATERIALS AND METHODS}

The design of this study was based on CLSI guideline M37-A3 (CLSI 2008). The QC strains Escherichia coli (ATCC 25922; NCIMB 12210) and Aeromonas salmonicida (ATCC 33658; NCIMB 1102) were tested by 9 laboratories using broth microdilution methods developed for testing Flavobacterium psychrophilum and F. columnare (Darwish et al. 2008, C. M. Gieseker et al. unpubl.). Both $\mathrm{QC}$ strains were tested at $18^{\circ} \mathrm{C}(92-96 \mathrm{~h})$ and $28^{\circ} \mathrm{C}(44-48 \mathrm{~h})$ using 3 different lots of diluted $\left(4 \mathrm{~g} \mathrm{l}^{-1}\right)$ cation-adjusted MHB (CAMHB). All laboratories repeated each test 10 times. Each replicate had 3 panels (media lots 1, 2, and $3 ; 3$ panels $\times 10$ replicates $=30$ replicates $l a b^{-1}$ for each drug/strain/temperature combination).

\section{Participating laboratories}

Nine laboratories participated in the standardization trial. The laboratories were the Food and Drug Administration, Center for Veterinary Medicine, Office of Research (Laurel, MD, USA; FDA/CVM/ OR); Animal Health Laboratory, Department of Primary Industries, Parks, Water \& Environment (Launceston, Tasmania, Australia); National Veterinary Institute, Technical University of Denmark (Frederiksberg, Denmark); Harry K. Dupree Stuttgart National Aquaculture Research Center (Stuttgart, AR, USA); Mississippi State University, College of Veterinary Medicine (Stoneville, MS, USA); University of Wisconsin Veterinary Diagnostic Laboratory (Madison, WI, USA); Washington Animal Disease Laboratory (Pullman, WA, USA); Inland Aquatic Animal Health Research Institute, Department of Fisheries, Kasetsart University Campus (Jaktujak, Bangkok, Thailand); and the Animal Disease Diagnostic Laboratory, Purdue University (West Lafayette, IN, USA). All 9 laboratories completed testing for the trial. The data presented are based on 8 laboratories for Escherichia coli ATCC 25922 and 7 labs for Aeromonas salmonicida ATCC 33658. One laboratory admitted making mistakes on their MIC interpretations; therefore, the data from that laboratory were excluded from the analysis. In addition, another laboratory could only test E. coli due to import restrictions against $A$. salmonicida.

\section{Broth microdilution panels and test media}

Custom, commercially prepared dry-form 96-well broth microdilution panels were purchased from
Trek Diagnostic Systems. Each well had dried residue of a separate 2 -fold dilution of 1 of 10 antimicrobials. Ten dilutions were tested for each of the following antimicrobials: ampicillin (0.03-16 $\mathrm{\mu g}$ $\left.\mathrm{ml}^{-1}\right)$, enrofloxacin $\left(0.001-0.5 \mu \mathrm{g} \mathrm{ml}^{-1}\right)$, erythromycin $\left(0.25-128 \mu \mathrm{g} \mathrm{ml}^{-1}\right)$, florfenicol $\left(0.12-64 \mu \mathrm{g} \mathrm{ml}^{-1}\right)$, flumequine $\left(0.004-2 \mu \mathrm{g} \mathrm{ml}^{-1}\right)$, oxolinic acid $(0.002-$ $\left.1 \mu \mathrm{g} \mathrm{ml}^{-1}\right)$, oxytetracycline $\left(0.015-8 \mu \mathrm{g} \mathrm{ml}^{-1}\right)$, and ormetoprim/sulfadimethoxine $(0.008 / 0.15-4 / 76 \mu \mathrm{g}$ $\mathrm{ml}^{-1}$ ). Seven dilutions were tested of gentamicin $\left(0.03-2 \mu \mathrm{g} \mathrm{ml}^{-1}\right)$ and trimethoprim/sulfamethoxazole $\left(0.008 / 0.15-0.5 / 9.5 \mathrm{\mu g} \mathrm{ml}^{-1}\right)$.

Three separate lots of broth were made from dehydrated powders manufactured by BBL ${ }^{\mathrm{TM}}(212322$, lot 7331751) and Difco ${ }^{\mathrm{TM}}$ (275710, lot 8127115) (BectonDickinson), and Oxoid (CM0405, lot 597351). Aliquots $(11 \mathrm{ml})$ of each broth were prepared by Trek Diagnostics Systems. Calcium (4 $\mathrm{mg} \mathrm{l}^{-1}$ ) and magnesium $\left(2 \mathrm{mg} \mathrm{l}^{-1}\right)$ cations were added as per CLSI guidelines if the prepared media were not already supplemented.

\section{Test bacteria and test conditions}

American Type Culture Collection (ATCC, Manassas, Virginia, USA) reference strains of Escherichia coli ATCC 25922 and Aeromonas salmonicida ATCC 33658 were incubated at $18^{\circ} \mathrm{C}$ for 92 to $96 \mathrm{~h}$ and at $28^{\circ} \mathrm{C}$ for 44 to $48 \mathrm{~h}$ in diluted $\left(4 \mathrm{~g} \mathrm{l}^{-1}\right)$ CAMHB.

\section{Broth microdilution susceptibility testing}

Tests were conducted in each laboratory over a minimum of $3 \mathrm{~d}$ with a maximum of 4 replicates $\mathrm{d}^{-1}$. Each laboratory (besides the one mentioned above) tested 10 replicates of each strain at both temperatures. Each replicate consisted of three 96-well panels, 1 panel for each lot of broth.

Prior to each test day, strains were subcultured twice on tryptic soy agar supplemented with $5 \%$ sheep blood. On each test day, a single suspension was prepared of each strain to a predetermined turbidity measured by colorimeter (0.5 McFarland), spectrophotometer ( 0.08 to 0.13 at $\left.\mathrm{OD}_{625}\right)$, or turbidimeter (20-30 NTUs).

Fifty-five $\mu \mathrm{l}$ of the cell suspension was added to each $11 \mathrm{ml}$ aliquot of broth (1:200 dilution). Each $11 \mathrm{ml}$ aliquot of broth was used to inoculate into a 96well broth microdilution panel. A Sensititre ${ }^{\circledR}$ autoinoculator (Trek Diagnostic Systems, 3 labs) or a multichannel pipette (6 labs) was used to add $100 \mu \mathrm{l}$ 
of the inoculated broth to each well. To prevent contamination and dehydration, plastic adhesive seals were immediately attached to the panels covering the top of the wells. Within 15 min of inoculation, the panels were placed in their respective incubators. No more than 4 panels were stacked together to achieve a uniform temperature across the panels.

Actual cell densities were determined using a colony count procedure whereby 2 panels on each test day were arbitrarily chosen for each QC strain (one each at 18 and $28^{\circ} \mathrm{C}$ ). Ten $\mu \mathrm{l}$ was removed from the positive control well and placed in $10 \mathrm{ml}$ sterile saline (1:1000 dilution). A $100 \mu$ l aliquot was evenly spread on a tryptic soy agar plate supplemented with $5 \%$ sheep blood. Colony count plates were incubated under the same conditions (temperature and time) as the 96-well panels, and colony-forming units (CFUs) were counted at the same time MICs were determined. Means and standard deviations (SD) of CFU $\mathrm{ml}^{-1}$ were calculated for each drug/strain/temperature combination across all replicates.

After the appropriate incubation period, the panel seal was removed to read panels. Panels were examined for growth in the wells, either as a pellet or turbidity. The MIC was the first well in the dilution series without growth. When interpreting results in wells with the bacteriostatic sulfonamides, growth $<80 \%$ of the pellet density in the positive control well was recorded as growth limited, indicative of a bacteriostatic effect evident as a trailing endpoint. Where this occurred, the MIC was established by identifying the well with $50 \%$ growth when compared with the positive control well. The next highest dilution well adjacent to the $50 \%$ growth well was assumed to have approximately $80 \%$ growth; therefore, the concentration in the well with $50 \%$ growth inhibition was considered the MIC.

\section{Data analysis}

The data were pooled into frequency distributions by broth lot, and also by laboratory. Each drug/ strain/temperature combination was analyzed separately for MIC mean, mode, median, minimum, maximum, and range.

All MIC data were entered into RangeFinder; a specialized Excel spreadsheet program that analyzes antimicrobial susceptibility testing data from CLSI standardization trials (Turnidge \& Bordash 2007). RangeFinder calculated a QC range, number of 2 -fold dilutions in the range, and the percent of observations captured by the calculated range.
Frequency distributions and histograms for each $\mathrm{drug} / \mathrm{strain} /$ temperature combination were used to also determine $\mathrm{QC}$ ranges using the median method developed by Gavan et al. (1981). Ideally, the QC ranges encompassed $95 \%$ of the observations and spanned 3 drug concentrations centered on the mode of the distribution. If data were skewed in one direction, where the MIC frequency at the 2-fold dilution immediately adjacent to the mode was $\geq 60 \%$ of MIC frequency at the mode, an additional 2-fold dilution was added to the final proposed $\mathrm{QC}$ range. The CLSI's VAST - Aquaculture Working Group compared the QC ranges estimated by the Gavan and RangeFinder methods to determine proposed QC ranges for each drug/strain/temperature combination. Both methods use arbitrary limits that require expert opinion.

\section{Confirmation of the drug concentration on the custom dry-form broth microdilution panels}

One laboratory (FDA/CVM/OR) followed the same procedures used in the standardization trial to test 5 subcultures of Escherichia coli ATCC 25922 and 5 subcultures of Aeromonas salmonicida ATCC 33658 in undiluted CAMHB to confirm the potency of the drugs on the panels. The testing was repeated 3 times, and each replicate was prepared on a separate day. Tests were conducted at 22 and $28^{\circ} \mathrm{C}$ according to the CLSI M49-A guideline. Spread plate colony counts were also prepared identically as described previously to confirm cell densities on each day testing was conducted. Drug potencies were considered acceptable if MIC test results from the $2 \mathrm{QC}$ strains on the custom dryform panels were within the acceptable ranges listed in the M49-A guideline.

\section{RESULTS AND DISCUSSION}

\section{Standardization trial}

Using standard AST methods makes it easier for laboratories to reliably share data, monitor development of drug resistance, and provide consistent clinical recommendations. Proper QC procedures with expected test results are required to confirm method performance. Miller et al. $(2003,2005)$ established the first standard reference disk diffusion and MIC testing methods for non-fastidious aquatic bacterial pathogens (CLSI 2006a,b). These organisms include 
members of Enterobacteriaceae and Vibrionaceae, and Aeromonas salmonicida, A. hydrophila, and other mesophilic aeromonads, Pseudomonas spp., Plesiomonas shigelloides, and Shewanella spp. Many fastidious aquatic bacteria are also important fish pathogens. In particular, the pathogenic gliding bacteria Flavobacterium columnare and F. psychrophilum cause disease and major economic loss for a wide variety of freshwater aquaculture industries. Recent approval of antimicrobials in the US to control mortality of fish infected with $F$. columnare and F. psychrophilum have further fueled a need for standard AST methods for these fastidious organisms. Our research directly addresses this issue and reports the results of a standardization trial to set MIC QC ranges for testing F. columnare and F. psychrophilum.

The proposed QC ranges determined by the CLSI VAST - Aquaculture Working Group were presented to the VAST Subcommittee and accepted with minor revisions to be included in the next edition of the M49-A guideline for dilution susceptibility testing of bacteria isolated from aquatic animals (CLSI 2006b). Table 1 provides the lot-by-lot comparison of the MIC results from our standardization trial. No laboratory was consistently different, although in some cases a laboratory had some MIC results outside of the majority ( $95 \%$ ) of the data distribution. A visual analysis comparing data by broth lot showed that all lots consistently agreed across the laboratories. Tables 2 to 5 summarize the MIC results and QC limits approved by the CLSI VAST Subcommittee for Escherichia coli ATCC 25922 and Aeromonas salmonicida ATCC 33658. Most of the MICs observed at both temperatures for A. salmonicida ATCC 33658 were centered on a single median MIC \pm 1 two-fold drug dilution (e.g. Fig. 1). In 2 cases, enrofloxacin at $18^{\circ} \mathrm{C}$ and ormetoprim/sulfadimethoxine at $18^{\circ} \mathrm{C}$ (Fig. 2), a QC range that spanned 4 dilutions was approved since the MIC distribution was asymmetric and had a frequency adjacent to the median that was $>60 \%$ of the frequency of the median MIC. More of the approved QC ranges for E. coli ATCC 25922 were 4 dilutions. This was the case at $28^{\circ} \mathrm{C}$ for 4 of the 9 drugs, and at $18^{\circ} \mathrm{C}$ for 3 of 7 drugs; in addition, because of inadequate data, $\mathrm{QC}$ ranges could not be established for enrofloxacin and ormetoprim/sulfadimethoxine at $18^{\circ} \mathrm{C}$.

No MIC QC ranges could be set for gentamicin since a majority of laboratories observed MICs below the test range $\left(\leq 0.03 \mu \mathrm{g} \mathrm{ml}^{-1}\right)$. When compared to frozen-form panels with the same drug format (performed by 1 laboratory, FDA/CVM/OR), genta-

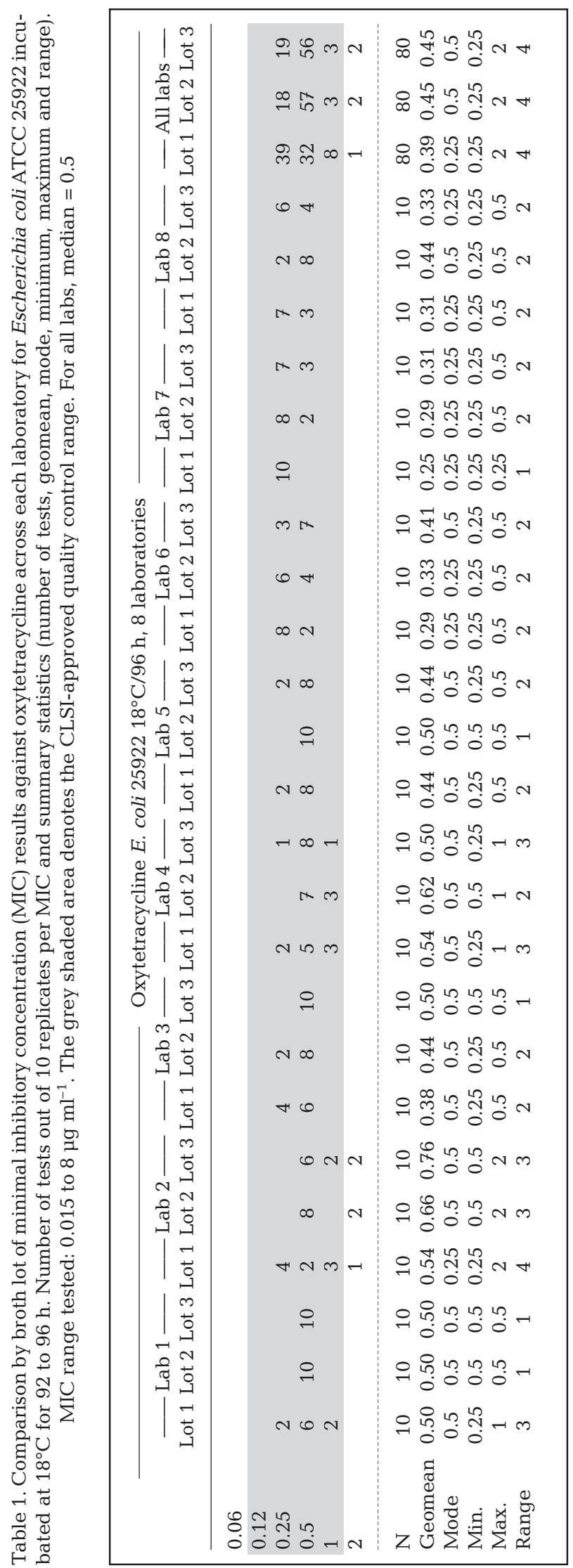


Table 2. Minimal inhibitory concentration (MIC) results for Escherichia coli ATCC 25922 incubated at $28 \pm 2{ }^{\circ} \mathrm{C}$ for 44 to $48 \mathrm{~h}$ in diluted $\left(4 \mathrm{~g} \mathrm{l}^{-1}\right)$ cation-adjusted Mueller-Hinton broth against 9 antimicrobials. QC: quality control

\begin{tabular}{|c|c|c|c|c|c|c|}
\hline $\begin{array}{l}\text { Antimicrobial } \\
\text { agent }\end{array}$ & $\begin{array}{l}\text { Testing range } \\
\quad\left(\mu \mathrm{gl}^{-1}\right)\end{array}$ & $\begin{array}{l}\begin{array}{c}\text { Inter-laboratory } \\
\text { range }\end{array} \\
\text { d }\end{array}$ & $\begin{array}{l}\text { MIC }\left(\mu \mathrm{g} \mathrm{ml}^{-1}\right. \\
\text { Median }\end{array}$ & $\begin{array}{l}\text { CLSI-approved } \\
\text { QC range }\end{array}$ & $\begin{array}{c}\text { No. of } \\
\text { dilutions in } \\
\text { QC range }\end{array}$ & $\begin{array}{l}\text { \% within } \\
\mathrm{QC} \text { range } \\
(\mathrm{n}=239)\end{array}$ \\
\hline Ampicillin & $0.03-16$ & $1-4$ & 2 & $1-4$ & 3 & 100.0 \\
\hline Enrofloxacin & $0.001-0.5$ & $0.004-0.015$ & 0.008 & $0.002-0.015$ & 4 & 100.0 \\
\hline Erythromycin & $0.25-128$ & $4-64$ & 32 & $16-64$ & 3 & 94.6 \\
\hline Florfenicol & $0.12-64$ & $1-8$ & 4 & $2-8$ & 3 & 99.6 \\
\hline Flumequine & $0.004-2$ & $0.12-0.5$ & 0.25 & $0.06-0.5$ & 4 & 100.0 \\
\hline $\begin{array}{l}\text { Ormetoprim/ } \\
\text { sulfadimethoxine }^{\mathrm{a}}\end{array}$ & $0.008 / 0.15-4 / 76$ & $0.06 / 1.19-0.5 / 9.5$ & $0.25 / 4.75$ & $0.12 / 2.38-0.5 / 9.5$ & 3 & 97.1 \\
\hline Oxolinic acid & $0.002-1$ & $0.06-0.25$ & 0.06 & $0.03-0.12$ & 3 & 99.6 \\
\hline Oxytetracycline & $0.015-8$ & $0.12-1$ & 0.5 & $0.12-1$ & 4 & 100.0 \\
\hline $\begin{array}{l}\text { Trimethoprim/ } \\
\text { sulfamethoxazole }^{\mathrm{b}}\end{array}$ & $0.008 / 0.15-0.5 / 9.5$ & $0.015 / 0.30-0.06 / 1.19$ & $0.06 / 1.19$ & $0.015 / 0.30-0.12 / 2.38$ & 4 & $100.0^{c}$ \\
\hline $\begin{array}{l}{ }^{a} \text { First (second) value } \\
{ }^{b} \text { First (second) value } \\
{ }^{c} n=238\end{array}$ & $\begin{array}{l}\text { indicates concentrat } \\
\text { indicates concentrat }\end{array}$ & $\begin{array}{l}\text { tion of ormetoprim (sulf } \\
\text { tion of trimethoprim (su }\end{array}$ & $\begin{array}{l}\text { fadimethoxir } \\
\text { dlfamethoxaz }\end{array}$ & $\begin{array}{l}\text { ne) } \\
\text { zole) }\end{array}$ & & \\
\hline
\end{tabular}

Table 3. Minimal inhibitory concentration (MIC) results of Escherichia coli ATCC 25922 incubated at $18 \pm 2{ }^{\circ} \mathrm{C}$ for 92 to $96 \mathrm{~h}$ in diluted $\left(4 \mathrm{~g} \mathrm{l}^{-1}\right)$ cation-adjusted Mueller-Hinton broth against 9 antimicrobials. QC: quality control

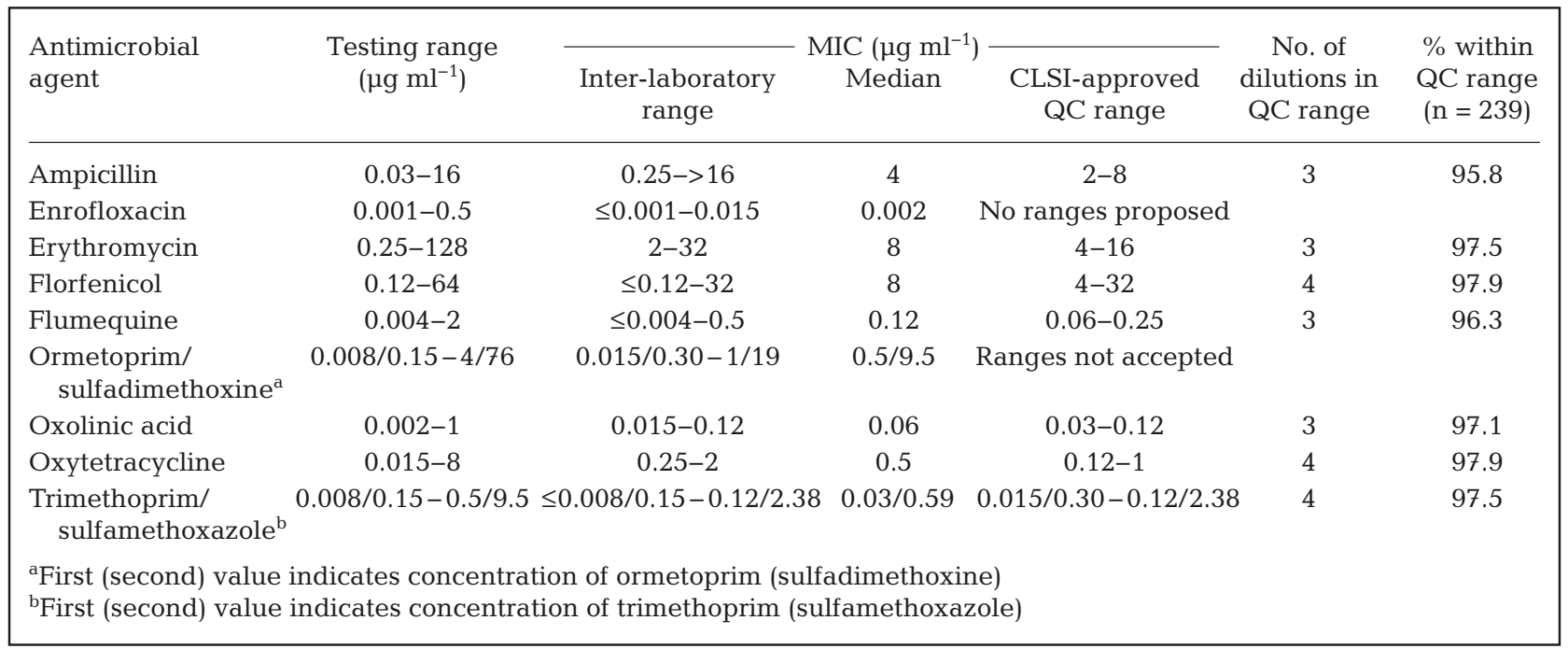

micin MICs from the dry-form panels were still observed to be below the test concentration range (data not shown). However, gentamicin MIC results were in range when both $\mathrm{QC}$ strains were tested with the dry-form panels in full strength CAMHB in this study (below) and by the manufacturer. We opted to use dry-form panels since these panels could withstand potentially longer transit times, and were shown to perform well in a similar standardization trial (Miller et al. 2005). Miller et al. (2005) also found that MIC results on dry-form and frozen-form broth microdilution panels agreed for the same QC strains.
Colony count data tracking approximated the final target concentration of approximately $5 \times 10^{5} \mathrm{CFU}$ $\mathrm{ml}^{-1}$ bacteria as recommended by the CLSI (2006b). The mean (SD) CFU ml ${ }^{-1}$ for Aeromonas salmonicida ATCC 33658 was $4.0 \times 10^{5}\left(1.8 \times 10^{5}\right)$ at $18^{\circ} \mathrm{C}$ and $4.3 \times 10^{5}\left(1.7 \times 10^{5}\right)$ at $28^{\circ} \mathrm{C}$. The mean (SD) CFU ml ${ }^{-1}$ for Escherichia coli ATCC 25922 was $3.3 \times 10^{5}(1.9 \times$ $\left.10^{5}\right)$ at $18^{\circ} \mathrm{C}$ and $4.5 \times 10^{5}\left(1.6 \times 10^{5}\right)$ at $28^{\circ} \mathrm{C}$. No trends were observed between $\mathrm{MIC}$ results and low/high cell densities, indicating that the variability in the cell densities did not markedly affect MIC results. 
Table 4. Minimal inhibitory concentration (MIC) results of Aeromonas salmonicida subsp. salmonicida ATCC 33658 incubated at $28 \pm 2{ }^{\circ} \mathrm{C}$ for 44 to $48 \mathrm{~h}$ in diluted $\left(4 \mathrm{~g} \mathrm{l}^{-1}\right)$ cation-adjusted Mueller-Hinton broth against 9 antimicrobials. QC: quality control

\begin{tabular}{|c|c|c|c|c|c|c|}
\hline $\begin{array}{l}\text { Antimicrobial } \\
\text { agent }\end{array}$ & $\begin{array}{l}\text { Testing range } \\
\qquad\left(\mu \mathrm{g} \mathrm{ml}^{-1}\right)\end{array}$ & $\begin{array}{l}\begin{array}{c}\text { Inter-laboratory } \\
\text { range }\end{array} \\
1\end{array}$ & $\begin{array}{l}\text { MIC }\left(\mu g \mathrm{ml}^{-1}\right) \\
\quad \text { Median }\end{array}$ & $\begin{array}{c}\text { CLSI-approved } \\
\text { QC range }\end{array}$ & $\begin{array}{l}\text { No. of } \\
\text { dilutions in } \\
\text { QC range }\end{array}$ & $\begin{array}{l}\% \text { within } \\
\text { QC range } \\
(\mathrm{n}=239)\end{array}$ \\
\hline Ampicillin & $0.03-16$ & $0.12-16$ & 0.12 & $0.06-0.25$ & 3 & 99.0 \\
\hline Enrofloxacin & $0.001-0.5$ & $0.008-0.015$ & 0.008 & $0.004-0.015$ & 3 & 100.0 \\
\hline Erythromycin & $0.25-128$ & $1-16$ & 8 & $4-16$ & 3 & 99.5 \\
\hline Florfenicol & $0.12-64$ & $0.5-2$ & 0.5 & $0.25-1$ & 3 & 99.5 \\
\hline Flumequine & $0.004-2$ & $0.015-0.06$ & 0.03 & $0.015-0.06$ & 3 & 100.0 \\
\hline $\begin{array}{l}\text { Ormetoprim/ } \\
\text { sulfadimethoxine }\end{array}$ & $0.008 / 0.15-4 / 76$ & $0.06 / 1.19-0.5 / 9.5$ & $0.12 / 2.38$ & $0.06 / 1.19-0.25 / 4.75$ & 3 & 99.5 \\
\hline Oxolinic acid & $0.002-1$ & $0.008-0.06$ & 0.015 & $0.008-0.03$ & 3 & 99.5 \\
\hline Oxytetracycline & $0.015-8$ & $0.12-0.5$ & 0.12 & $0.06-0.25$ & 3 & 99.5 \\
\hline $\begin{array}{l}\text { Trimethoprim/ } \\
\text { sulfamethoxazole }^{\mathrm{b}}\end{array}$ & $0.008 / 0.15-0.5 / 9.5$ & $\leq 0.008 / 0.15-0.12 / 2.38$ & 8 0.06/1.19 & $0.03 / 0.59-0.12 / 2.38$ & 3 & 99.5 \\
\hline $\begin{array}{l}{ }^{\mathrm{a}} \text { First (second) value i } \\
{ }^{\mathrm{b}} \text { First (second) value i }\end{array}$ & $\begin{array}{l}\text { indicates concentrati } \\
\text { indicates concentrati }\end{array}$ & $\begin{array}{l}\text { ion of ormetoprim (sulf } \\
\text { ion of trimethoprim (su }\end{array}$ & $\begin{array}{l}\text { fadimethoxine } \\
\text { ulfamethoxazo }\end{array}$ & $\begin{array}{l}\text { e) } \\
\text { ole) }\end{array}$ & & \\
\hline
\end{tabular}

Table 5. Minimal inhibitory concentration (MIC) results of Aeromonas salmonicida subsp. salmonicida ATCC 33658 incubated at $18 \pm 2^{\circ} \mathrm{C}$ for 92 to $96 \mathrm{~h}$ in diluted $\left(4 \mathrm{~g} \mathrm{l}^{-1}\right)$ cation-adjusted Mueller-Hinton broth against 9 antimicrobials. QC: quality control

\begin{tabular}{|c|c|c|c|c|c|c|}
\hline $\begin{array}{l}\text { Antimicrobial } \\
\text { agent }\end{array}$ & $\begin{array}{l}\text { Testing range } \\
\quad\left(\mu \mathrm{g} \mathrm{ml}^{-1}\right)\end{array}$ & $\begin{array}{l}\begin{array}{l}\text { Inter-laboratory } \\
\text { range }\end{array} \\
\text { I }\end{array}$ & $\begin{array}{c}\text { MIC }\left(\mu g \mathrm{ml}^{-1}\right) \\
\text { Median }\end{array}$ & $\begin{array}{l}\text { CLSI-approved } \\
\text { QC range }\end{array}$ & $\begin{array}{c}\text { No. of } \\
\text { dilutions in } \\
\text { QC range }\end{array}$ & $\begin{array}{c}\% \text { within } \\
\mathrm{QC} \text { range } \\
(\mathrm{n}=239)\end{array}$ \\
\hline Ampicillin & $0.03-16$ & $0.12-1$ & 0.12 & $0.06-0.25$ & 3 & 98.1 \\
\hline Enrofloxacin & $0.001-0.5$ & $0.004-0.015$ & 0.008 & $0.004-0.03$ & 4 & 100.0 \\
\hline Erythromycin & $0.25-128$ & $4-16$ & 8 & $4-16$ & 3 & 100.0 \\
\hline Florfenicol & $0.12-64$ & $0.5-2$ & 0.5 & $0.25-1$ & 3 & 99.5 \\
\hline Flumequine & $0.004-2$ & $0.03-0.12$ & 0.03 & $0.015-0.06$ & 3 & 98.1 \\
\hline $\begin{array}{l}\text { Ormetoprim/ } \\
\text { sulfadimethoxine }\end{array}$ & $0.008 / 0.15-4 / 76$ & $0.06 / 1.19-0.25 / 4.75$ & $0.06 / 1.19$ & $0.03 / 0.59-0.25 / 4.75$ & 4 & 99.5 \\
\hline Oxolinic acid & $0.002-1$ & $0.008-0.06$ & 0.015 & $0.008-0.03$ & 3 & 99.5 \\
\hline Oxytetracycline & $0.015-8$ & $0.12-1$ & 0.12 & $0.06-0.25$ & 3 & 99.5 \\
\hline $\begin{array}{l}\text { Trimethoprim/ } \\
\text { sulfamethoxazole }\end{array}$ & $0.008 / 0.15-0.5 / 9.5$ & $0.015 / 0.30-0.06 / 1.19$ & $9 \quad 0.03 / 0.59$ & $0.015 / 0.30-0.06 / 1.19$ & 3 & 100.0 \\
\hline
\end{tabular}

\section{Validation of drug concentrations with undiluted CAMHB}

The established QC ranges from the M49-A CLSI guideline (CLSI 2006b) for broth microdilution testing in full strength CAMHB of Aeromonas salmonicida ATCC 33658 and Escherichia coli ATCC 25922 at $22^{\circ} \mathrm{C}$ ( 24 and $\left.48 \mathrm{~h}\right)$ and $28^{\circ} \mathrm{C}(24 \mathrm{~h})$ were used to validate the drug concentrations of the custom dryform broth microdilution panels. All MIC results at $22^{\circ} \mathrm{C}$ were within the accepted $\mathrm{QC}$ ranges and were in agreement among the replicates within \pm 1 two- fold dilution except for erythromycin results for A. salmonicida. At 24 h, 9 of 15 erythromycin test results were outside of the accepted parameters, but by $48 \mathrm{~h}$, only 2 of 15 were out of range.

All of the $28^{\circ} \mathrm{C}$ Aeromonas salmonicida erythromycin $\mathrm{MIC}$ results were in the QC range, but were concentrated at the lowest MIC. However, in the standardization trial, the median erythromycin MIC data in diluted CAMHB for A. salmonicida at $18^{\circ} \mathrm{C}(96 \mathrm{~h})$ was very similar to $28^{\circ} \mathrm{C}(48 \mathrm{~h}$; Tables $4 \& 5)$. At least $99.5 \%$ of the MIC data was within the same 2-fold dilution range with the same median at both temperatures. 


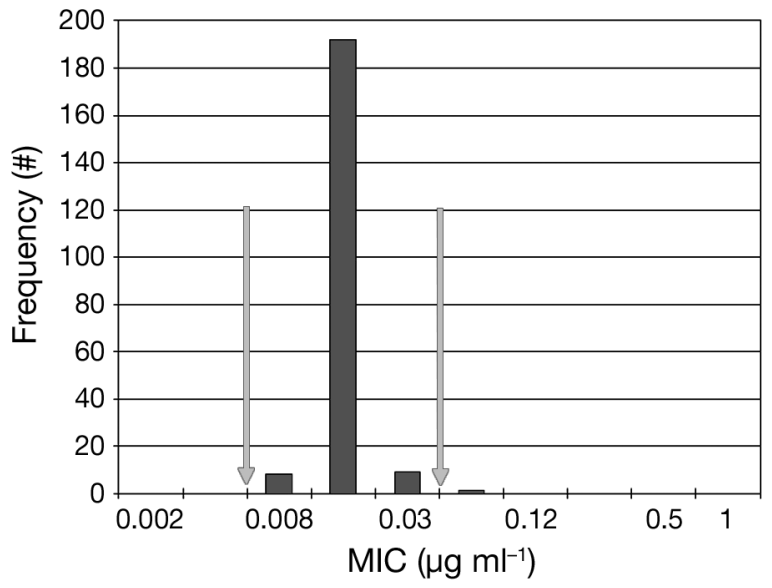

Fig. 1. Minimal inhibitory concentration (MIC) frequency distribution of Aeromonas salmonicida subsp. salmonicida ATCC 33658 against oxolinic acid, incubated at $18^{\circ} \mathrm{C}$ for $96 \mathrm{~h}$. Arrows indicate the 3-dilution CLSI-approved MIC quality control range

The data from this validation experiment were presented to the CLSI VAST committee concurrently with the standardization trial, and the results confirmed that drug concentration ranges were valid on the dry-form panels used in the standardization trial.

\section{CONCLUSIONS}

Consistent MIC results across the laboratories showed that Escherichia coli ATCC 25922 and Aeromonas salmonicida ATCC 33658 are reliable QC strains for broth microdilution testing at 18 and $28^{\circ} \mathrm{C}$ in diluted CAMHB $\left(4 \mathrm{~g} \mathrm{l}^{-1}\right)$. These strains can be used

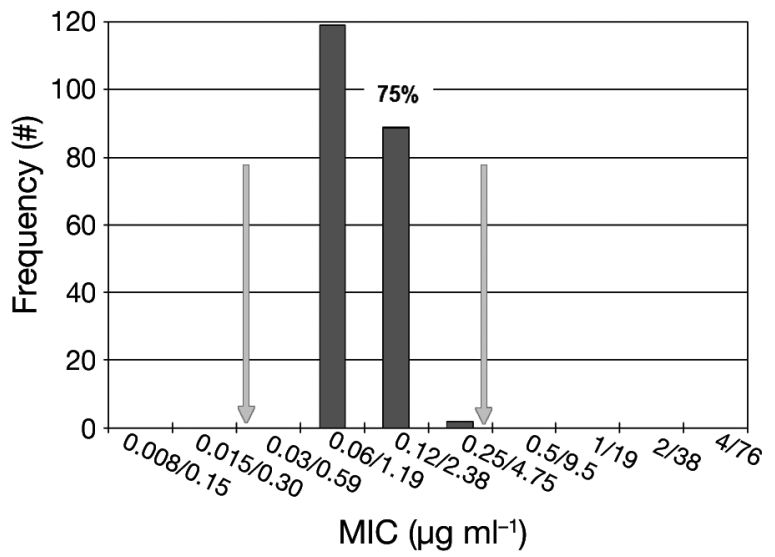

Fig. 2. Minimal inhibitory concentration (MIC) frequency distribution of Aeromonas salmonicida subsp. salmonicida ATCC 33658 against ormetoprim/sulfadimethoxine, incubated at $18^{\circ} \mathrm{C}$ for $96 \mathrm{~h}$. Arrows indicate the CLSI-approved MIC quality control range. A MIC range spanning 4 dilutions was approved, since the number of data points at $0.12 / 2.38 \mu \mathrm{g} \mathrm{ml}^{-1}$ was $75 \%$ of the data points in the mode, $0.06 / 1.19 \mu \mathrm{g} \mathrm{ml}^{-1}$

for QC testing of clinical isolates of Flavobacterium columnare and F. psychrophilum.

CLSI testing guidelines are intended to be living documents that are continually updated as new methods and approaches are developed. This newly standardized AST method for Flavobacteria and the MIC QC ranges provided in Table 6 will be included in the next edition of the CLSI M49-A guideline. We hope that our work as well as the work of Miller et al. $(2003,2005)$ will serve as helpful resources to aid in continued development of more standardized AST methods for other important aquatic bacterial pathogens.

Table 6. Summary of CLSI-approved minimal inhibitory concentration quality control ranges $\left(\mu \mathrm{g} \mathrm{ml}^{-1}\right)$ for broth dilution susceptibility testing in dilute $4 \mathrm{~g} \mathrm{l}^{-1}$ cation-adjusted Mueller-Hinton broth

\begin{tabular}{|c|c|c|c|c|}
\hline \multirow{2}{*}{$\begin{array}{l}\text { Antimicrobial } \\
\text { agent }\end{array}$} & \multicolumn{2}{|c|}{ Escherichia coli ATCC 25922} & \multicolumn{2}{|c|}{ Aeromonas salmonicida ATCC 33658} \\
\hline & $28^{\circ} \mathrm{C}, 44-48 \mathrm{~h}$ & $18^{\circ} \mathrm{C}, 92-96 \mathrm{~h}$ & $28^{\circ} \mathrm{C}, 44-48 \mathrm{~h}$ & $18^{\circ} \mathrm{C}, 92-96 \mathrm{~h}$ \\
\hline Ampicillin & $1-4$ & $2-8$ & $0.06-0.25$ & $0.06-0.25$ \\
\hline Enrofloxacin & $0.002-0.015$ & No ranges proposed & $0.004-0.015$ & $0.004-0.03$ \\
\hline Erythromycin & $16-64$ & $4-16$ & $4-16$ & $4-16$ \\
\hline Florfenicol & $2-8$ & $4-32$ & $0.25-1$ & $0.25-1$ \\
\hline Flumequine & $0.06-0.5$ & $0.06-0.25$ & $0.015-0.06$ & $0.015-0.06$ \\
\hline $\begin{array}{l}\text { Ormetoprim/ } \\
\text { sulfadimethoxine }{ }^{\mathrm{a}}\end{array}$ & $0.12 / 2.38-0.5 / 9.5$ & Ranges not accepted & $0.06 / 1.19-0.25 / 4.75$ & $0.03 / 0.59-0.25 / 4.75$ \\
\hline Oxolinic acid & $0.03-0.12$ & $0.03-0.12$ & $0.008-0.03$ & $0.008-0.03$ \\
\hline Oxytetracycline & $0.12-1$ & $0.12-1$ & $0.06-0.25$ & $0.06-0.25$ \\
\hline $\begin{array}{l}\text { Trimethoprim/ } \\
\quad \text { sulfamethoxazole }\end{array}$ & $0.015 / 0.3-0.12 / 2.38$ & $0.015 / 0.3-0.12 / 2.38$ & $0.03 / 0.59-0.12 / 2.38$ & $0.015 / 0.3-0.06 / 1.19$ \\
\hline $\begin{array}{l}{ }^{\mathrm{a}} \text { First (second) value i } \\
{ }^{\mathrm{b}} \text { First (second) value i }\end{array}$ & $\begin{array}{l}\text { ates concentration } \\
\text { cates concentration }\end{array}$ & $\begin{array}{l}\text { rmetoprim (sulfadin } \\
\text { rimethoprim (sulfam }\end{array}$ & $\begin{array}{l}\text { e) } \\
\text { ole) }\end{array}$ & \\
\hline
\end{tabular}


Acknowledgements. We sincerely thank J. Brown and L. Gertman for their participation in the study, and R. Miller, R. Reimschuessel, C. Stine, E. Evans, and N. Hasbrouck for their review of the manuscript. We also thank S. Pratt for data review and C. Woods for support and advice.

\section{LITERATURE CITED}

Bernardet JF (1989) 'Flexibacter columnaris': first description in France and comparison with bacterial strains from other origins. Dis Aquat Org 6:37-44

Bernardet JF, Grimont PAD (1989) Deoxyribonucleic acid relatedness and phenotypic characterization of Flexibacter columnaris sp. nov., nom. rev., Flexibacter psychrophilus sp. nov., nom. rev., and Flexibacter maritimus Wakabayashi, Hikida, and Masumura 1986. Int J Syst Bacteriol 39:346-354

Bruun MS, Schmidt AS, Madsen L, Dalsgaard I (2000) Antimicrobial resistance patterns in Danish isolates of Flavobacterium psychrophilum. Aquaculture 187:201-212

CLSI (Clinical and Laboratory Standards Institute) (2006a) Methods for antimicrobial disk susceptibility testing of bacteria isolated from aquatic animals: approved guideline. Document M42-A. CLSI, Wayne, PA

CLSI (2006b) Methods for broth dilution susceptibility testing of bacteria isolated from aquatic animals: approved guideline. Document M49-A. CLSI, Wayne, PA

CLSI (2008) Development of in vitro susceptibility testing criteria and quality control parameters for veterinary antimicrobial agents; approved guideline, 3rd edn. Document M37-A3. CLSI, Wayne, PA

Darwish AM, Farmer BD, Hawke JP (2008) Improved method for minimum inhibitory concentration testing of Flavobacterium columnare. J Aquat Anim Health 20:185-191

Farmer BD (2004) Improved methods for the isolation and characterization of Flavobacterium columnare. MS thesis, Louisiana State University, Baton Rouge, LA

Gavan TL, Jones RN, Barry AL, Fuchs PC and others (1981) Quality control limits for ampicillin, carbenicillin, mezlocillin, and piperacillin disk diffusion susceptibility tests: a collaborative study. J Clin Microbiol 14:67-72

Hawke JP, Thune RL (1992) Systemic isolation and antimicrobial susceptibility of Cytophaga columnaris from commercially reared channel catfish. J Aquat Anim Health 4: 109-113

Editorial responsibility: David Bruno, Aberdeen, UK
Holt RA, Amandi A, Rohovec JS, Fryer JL (1989) Relation of water temperature to bacterial cold-water disease in Coho salmon, Chinook salmon, and rainbow trout. J Aquat Anim Health 1:94-101

Holt R, Rohovec JS, Fryer JL (1993) Bacterial coldwater disease. In: Inglis V, Roberts RJ, Bromage NR (eds) Bacterial diseases of fish. Blackwell Scientific Publications, Oxford, p 3-22

> Michel C, Kerouault B, Martin C (2003) Chloramphenicol and florfenicol susceptibility of fish-pathogenic bacteria isolated in France: comparison of minimum inhibitory concentration, using recommended provisory standards for fish bacteria. J Appl Microbiol 95:1008-1015

Miller RA, Walker RD, Baya A, Clemens K and others (2003) Antimicrobial susceptibility testing of aquatic bacteria: quality control disk diffusion ranges for Escherichia coli ATCC 25922 and Aeromonas salmonicida subsp. salmonicida ATCC 33658 at 22 and $28^{\circ} \mathrm{C}$. J Clin Microbiol 41: 4318-4323

> Miller RA, Walker RD, Carson J, Coles M and others (2005) Standardization of a broth microdilution susceptibility testing method to determine minimum inhibitory concentrations of aquatic bacteria. Dis Aquat Org 64: 211-222

> Nematollahi A, Decostere A, Pasmans F, Haesebrouck F (2003) Flavobacterium psychrophilum infections in salmonid fish. J Fish Dis 26:563-574

> Pulkkinen K, Suomalainen LR, Read AF, Ebert D, Rintamäki $\mathrm{P}$, Valtonen ET (2010) Intensive fish farming and the evolution of pathogen virulence: the case of columnaris disease in Finland. Proc R Soc Lond B Biol Sci 277:593-600

> Schmidt AS, Bruun MS, Dalsgaard I, Pedersen K, Larsen JL (2000) Occurrence of antimicrobial resistance in fishpathogenic and environmental bacteria associated with four Danish rainbow trout farms. Appl Environ Microbiol 66:4908-4915

Turnidge J, Bordash G (2007) Statistical methods for establishing quality control ranges for antibacterial agents in Clinical and Laboratory Standards Institute susceptibility testing. Antimicrob Agents Chemother 51:2483-2488

> Wagner BA, Wise DJ, Khoo LH, Terhune JS (2002) The epidemiology of bacterial diseases in food-size channel catfish. J Aquat Anim Health 14:263-272

Wakabayashi H, Egusa S (1966) Characteristics of a myxobacterium, Chondrococcus columnaris, isolated from diseased loaches. Bull Jpn Soc Sci Fish 32:1015-1022

Submitted: June 4, 2012; Accepted: August 27, 2012 Proofs received from author(s): November 2, 2012 